\title{
Evaluation and long-term conservation perspectives of woodland key habitat bryophyte and lichen indicators in Latgale
}

\author{
Anna Mežaka1, Sanita Putna ${ }^{2}$, Inga Erta ${ }^{3}$ \\ ${ }^{1}$ Research Institute for Regional Studies, Rezekne Higher Education Institution, \\ ${ }^{2}$ Nature Conservation Agency, \\ ${ }^{3}$ State Forest Service
}

\begin{abstract}
Nowadays human impact to habitats and species are stronger then ever before. Latvia is typical example of fragmented landscape, where forest patches are mixed with agricultural land and waterbodies. Latgale is one of typical such a fragmented landscape parts of Latvia. Around $6.41 \%$ of Latgalian forests were evaluated as Woodland Key Habitats (WKHs) or potential WKHs (PWKHs) after WKH inventory. The aim of this paper is to evaluate the current status and draw the further perspectives of WKH bryophyte and lichen indicator species conservation in Latgale. Data were analyzed with Generalized Linear model. In total 16 WKH types, suitable for bryophyte and lichen indicator species existence were identified in Latgale. As a result WKH type, forest stand age and area were significant factors influencing bryophyte and lichen specialist and indicator species richness in forest stand level. WKH status did not provide any official conservation status for habitats or species based on current legislation in Latvia. Therefore establishment of conservation areas as microreserves for habitats and species and Nature Reserves in areas, with high (P)WKH density is an effective tool for their long-term conservation in Latgale. Further scientific studies of bryophytes, lichens and WKHs are necessary for planning the best conservation scenarios taking into account also forest ecosystem services.
\end{abstract}

Keywords: Woodland key habitats, bryophytes, lichens, conservation.

\section{INTRODUCTION}

Habitat fragmentation is among the major threats of biodiversity loss worldwide [1], including forest ecosystems [2]. Forest fragmentation also decreases the species population sizes leading to the species extinction debt [3]. Latvia represents an example of fragmented forest landscape due to the past history of land-use [4]. Latgale show one of the most fragmented regions in Latvia, where maintaining forest landscape should play an especially significant role for the forest dwelling species conservation in a future.

Forest cover is around $38.6 \%$ of total area of Latgale. The highest forest cover represents northern and southern parts of Latgale. Several conservation categories exist in Latgale - National park, Protected landscape region, Nature Park, Nature Reserve, Microreserve, Nature monument for habitat conservation, including partly also forest habitat conservation [5].

Woodland key habitat (WKH) is an area which contains habitat specialists, that cannot sustainably survive in stands managed for timber production. A well-founded expectation that a habitat specialist exists within an area is a sufficient criterion for designating the area as a WKH. Potential WKH (PWKH) is a habitat, that if it is managed in such a way as to promote its biodiversity value, may become a WKH during the next 20 years in stands of pine and spruce, during the next 30 years in stands of oak, ash, lime, elm, and during the next 10 years in stands of aspen, birch and alder [6]. Around 3.4\% of Latvian State forests were evaluated as WKHs based on data obtained from WKH inventory projects (1999.-2003.). Around $6.41 \%$ of Latgale forest cover were evaluated as (P)WKHs [7]. The aim of WKH inventory was to found out the information about the (P)WKHs in state forest, identify biological value and suggest the suitable management activities for their conservation.

Several (P)WKH concentration areas with bryophyte and lichen specialist and indicator species hotspots were identified also in Latgale [8]. Today WKH status did not provide any official conservation status for habitats or species based on the current legislation in Latvia, but in many cases, these habitats correspond to microreserve criteria $[9,10]$.

Habitat specialist is a threatened species that is dependent on a certain level of quality in specific 
WKHs and will become extinct if these habitats are subject to detrimental treatment. Indicator species is a species that has rather high demands on its living conditions but not as high as those of a habitat specialist. WKHs in Latgale were inventored only in Latvian state forests [8]. Bryophytes and lichens are important forest dwelling organisms as they are sensitive to changes of forest microclimate and indicates specific conditions of $\mathrm{WKH}$, where also other organism groups may exist.

The aim of this paper is to evaluate the current status and draw the further perspectives of WKH bryophyte and lichen indicator species conservation in Latgale.

\section{MATERIALS AND METHODS}

Study area

The study area was located in Latgale, representing wide part of eastern Latvia (Fig. 1). The annual rainfall in Latgale vary from 540 to $650 \mathrm{~mm}$.
The average temperature in January is less than $-7^{\circ} \mathrm{C}$, the average temperature in July is more than $+17^{\circ} \mathrm{C}$ [11].

Data were obtained from WKH inventory collected in Latvian State forests from 1999 till 2007 in Latgale from Forest State Service data base. In total 32168 (P)WKHs from 16 WKH types were analyzed - aspen forest (APS), spring influenced forest (AVOT), beaver activity (BEBR), ravine forest (GRAV), giant tree (KOKS), riparian forest (KRAST), other deciduous forest (LAP), black alder wetland forest (MELN), mixed coniferous - deciduous forest (MIS), slope forest (NOGAZ), broad-leaved forest (PLAT), coniferous forest (SKUJ), spruce and mixed sprucewetland forest (SLAP EG), broad-leaved wetland forest (SLAP PL), pine and pine-birch wetland forest (SLAP_PR), wind fallen forest (VEJG) including $\mathrm{P}(\mathrm{WKH})$ area and forest stand age. $(\mathrm{P}) \mathrm{WKH}$ area varied from 0.1 ha to 28.3 ha and forest stand age from 10 to 224 years.

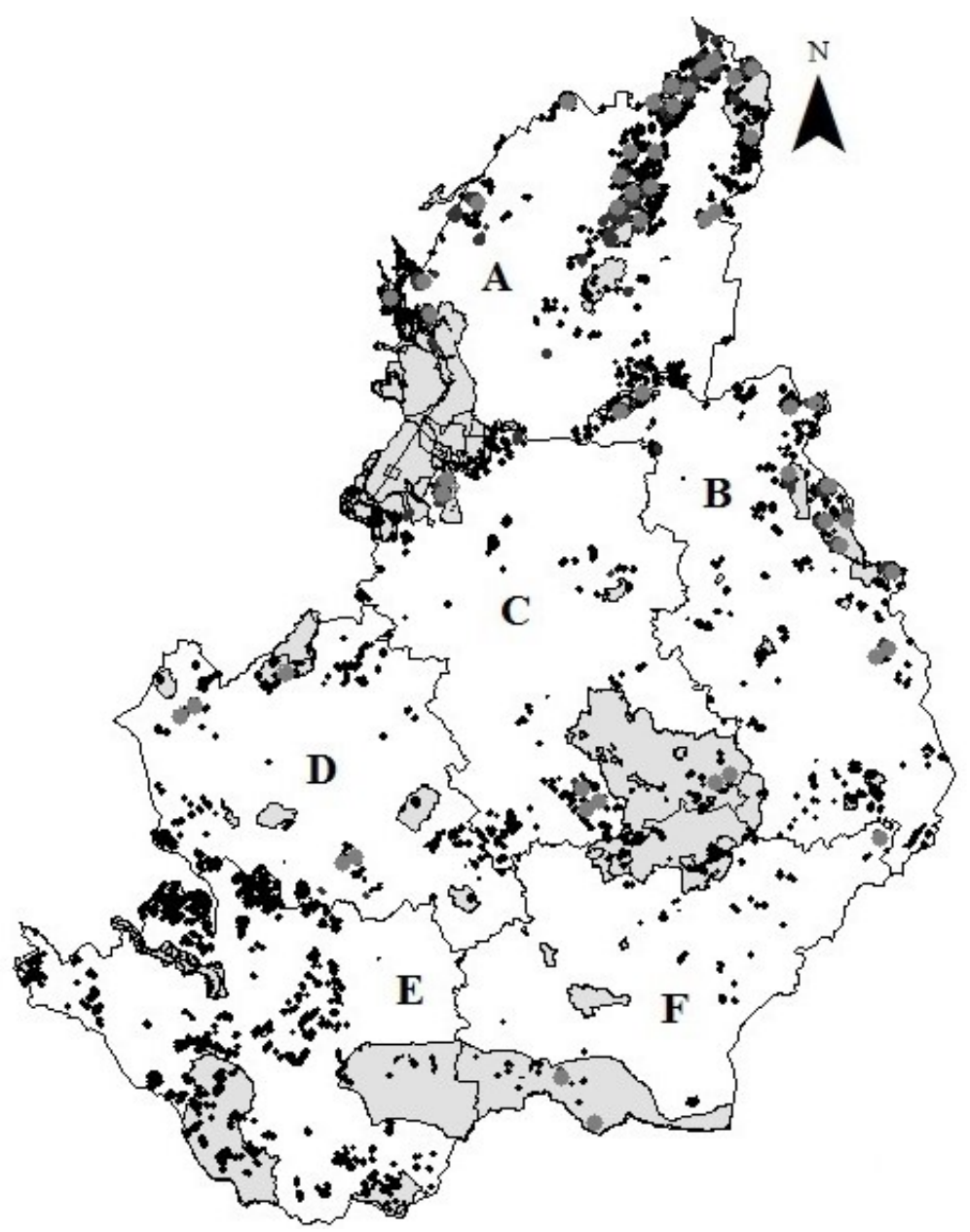

Fig. 1. The current valuable territories for forest conservation in Latgale. $\mathrm{P}(\mathrm{WKH})$ (black), microreserves (dark grey circle) and specially protected territories (light grey). A-Balvu district, B-Ludzas district, C-Rēzeknes district, D- Preiļu district, E- Daugavpils didtrict, FKrāslavas district. 


\section{Data analysis}

WKH indicator and specialist species were compiled as "indicator species" to facilitate the data analysis process in abstract, materials and methods, results and discussion, conclusions sections of this paper. The map with current valuable territories for forest conservation was generated with ESRI Arc View GIS 10.0 using database GIS Latvija 9.2.

Generalized linear model (GLM) with poisson family in R programme (Version 2.11.1) was applied for analyzing WKH lichen and bryophyte species indicators in relation to forest type, area and forest stand age. In total 16 bryophyte and lichen species occurrences in relation to (P)WKH type, area and stand age were analyzed (in total 32168 samples).

\section{RESULTS AND DISCUSSION}

WKHs are located in a highly fragmented landscape in Latgale (Fig.1), where wide agricultural lands and waterbodies are mixed with relatively small forest patches. Based on data from Razna national park [12] - around $50 \%$ of park area are covered by forests, but these forests are intensively managed and conservation of long-term biodiversity is threatened (73\% of all forest stands are less then 60 years old, older than 100 years are only $3 \%$ of forest stands). Forest cover in Nature Park "Daugavas loki", located in southern Latgale, is $58 \%$ of park area, around $45 \%$ of forest stands, are 51-100 years old. Forest stands older than 100 years cover $40 \%$ of forest area [13]. Based on data about WKH inventory - most of (P)WKHs are not located in specially protected territories (Fig.1). Therefore (P)WKHs outside the specially protected territories are forming clusters indicating also suitable conditions for WKH lichen and bryophyte indicator species existence. Such clusters may serve as hotspots for WKH bryophyte and lichen indicators noting suitable conditions for occurrence also for other organism groups.

In total 20 lichen and 17 bryophyte indicator species were found in studied (P)WKHs in Latgale. The most common lichen indicators in Latgale were Graphis scripta (921 records), Menegazzia terebrata (361 records), Arthonia spadicea (355 records), Lobaria pulmonaria (247 records). The most common bryophyte indicators - Neckera pennata (845 records), Homalia trichomanoides (788 records), Jamesoniella autumnalis (398 records).

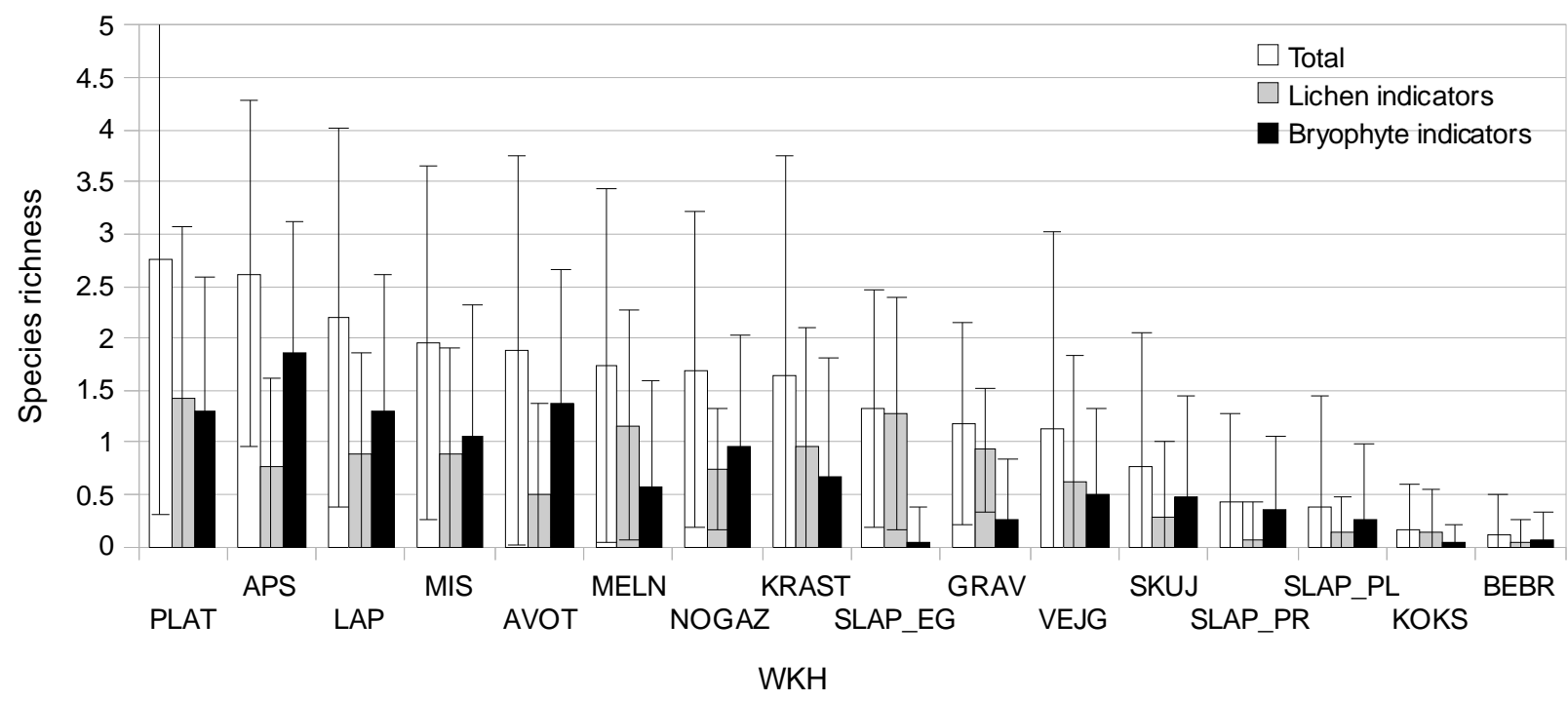

Fig. 2. The average bryophyte and lichen indicator richness among studied WKH types in Latgale. WKH abbreviations defined in Materials and methods section. Data include (P)WKHs.

Differences were found in bryophyte and lichen indicator species richness among studied WKH types (Fig. 2). The highest total and lichen indicator species richness was found in broad-leaved (P)WKHs, the highest bryophyte indicator richness was found in aspen (P)WKHs. These species richness differences may be explained with different microclimatic requirements for lichens and bryophytes. Previous studies noted the importance of deciduous forests for existence of epiphytic species being explained by suitable tree species and bark characters in Latvia $[14,15,16]$. 


\begin{tabular}{|c|c|c|c|c|c|c|}
\hline Variables & Z-value & $\mathrm{p}$ & Z-value & $\mathrm{p}$ & Z-value & $\mathrm{p}$ \\
\hline & \multicolumn{2}{|c|}{$\begin{array}{l}\text { Total indicator } \\
\text { richness }\end{array}$} & \multicolumn{2}{|c|}{$\begin{array}{l}\text { Bryophyte indicator } \\
\text { richness }\end{array}$} & \multicolumn{2}{|c|}{$\begin{array}{l}\text { Lichen indicator } \\
\text { richness }\end{array}$} \\
\hline Full model & 8.98 & $<0.01$ & 6.97 & $<0.01$ & -2.5 & 0.01 \\
\hline Size & 7.85 & $<0.01$ & 5.67 & $<0.01$ & 5.27 & $<0.01$ \\
\hline Age & -9.24 & $<0.01$ & -10.32 & $<0.01$ & -2.71 & $<0.01$ \\
\hline Beaver activity & -6.08 & $<0.01$ & -5.04 & $<0.01$ & -3.27 & $<0.01$ \\
\hline Ravine forest & -2.53 & 0.01 & -5.04 & $<0.01$ & 2.39 & 0.02 \\
\hline Giant tree & -5.36 & $<0.01$ & -3.75 & $<0.01$ & -2.51 & 0.01 \\
\hline Broad-leaved forest & 3.86 & $<0.01$ & - & - & 4.55 & $<0.01$ \\
\hline Aspen forest & 3.11 & $<0.01$ & 2.72 & $<0.01$ & - & - \\
\hline Coniferous forest & -5.45 & $<0.01$ & -4.57 & $<0.01$ & -2.16 & 0.03 \\
\hline Broad-leaved wetland forest & -3.96 & $<0.01$ & -3.16 & $<0.01$ & -2.13 & 0.03 \\
\hline Pine and pine-birch wetland forest & -9.81 & $<0.01$ & -6.66 & $<0.01$ & -6.91 & $<0.01$ \\
\hline Wind - fallen forest & -2.54 & 0.01 & -3.37 & $<0.01$ & - & - \\
\hline Riparian forest & - & - & -2.89 & $<0.01$ & 2.69 & $<0.01$ \\
\hline Black alder wetland forest & - & - & -6.29 & $<0.01$ & 3.98 & $<0.01$ \\
\hline Spruce and mixed spruce-wetland forest & - & - & -7.38 & $<0.01$ & 4.41 & $<0.01$ \\
\hline Other deciduous forest & - & - & - & - & 2.66 & $<0.01$ \\
\hline Mixed coniferous-deciduous forest & - & - & - & - & 2.83 & $<0.01$ \\
\hline
\end{tabular}

(P)WKH type was found as a significant factor influencing bryophyte and lichen species richness in forest stand level (Tab 1). However, some variations were found among total, bryophyte or lichen indicator richness groups in relation to forest type. These results showed, that different species groups have different requirements in demands of (P)WKH type, what is important to bear in mind for planning long-term conservation for bryophyte and lichen indicator species.

(P)WKH age and area were significant $(\mathrm{p}<0.05)$ factors in forest stand level explaining bryophyte and species indicator species richness. (P)WKH age was significantly related to lichen species diversity in Estonian forests [17], but Rogers and Ryel [18] did not find significant relationship between species richness and forest stand age. Forest stand area was found to be an important driver for long-term population existence [19] and epiphyte richness [20]. Both WKH age and area play an important role in species dispersal to suitable habitats and substrates. Bryophyte and lichen diaspores should pass long-distances in fragmented landscape until meet the suitable substrate and conditions for their long-term existence. Systematic conservation planning at landscape level is important for fragmented habitats as WKHs [21]. Fragmentation reflects severe conditions for species existing in fragmented forest patches. Establishment of network with WKHs is one of the steps towards the successful management of biodiversity suggested in Sweden.
Biodiversity conservation planning should take into account the landscape scale [2] as well as ecosystem services of forest habitats [23] and researchers as biologist's should be involved. Ecosystem services of Protected territories ensure the highest ecosystem services supply in terms of habitat preservation for threatened species, climate regulation, erosion control and water flow maintenance [24]. Further scientific studies of bryophytes, lichens and WKHs are necessary for planning the best conservation scenarious taking into account also forest ecosystem services.

Based on present results about (P)WKHs and bryophyte as well as lichen indicator species occurrence in these forests in Latgale, we suggest to stimulate and fasten the establishment of microreserves, where separate WKHs are located, but Nature Reserves should be established in areas, where density of WKHs is higher especially in northern, eastern and southern parts of Latgale for long-term conservation planning. Conservation priority should be given to older WKH stands. Establishment of Nature Reserves as wider conservation unit will gain higher benefit for WKHs as well as bryophyte and lichen indicator species conservation in long-term.

\section{CONCLUSIONS}

1) Latgale has strictly fragmented forest landscape, but forest patches with high biological value were 
left representing diversity of bryophyte and lichen indicator species in $16 \mathrm{WKH}$ types in relatively small forest patches.

2) The current conservation of WKH bryophyte and lichen indicator species is not enough for their long-term existence as most of suitable (P)WKHs are located outside of conservation areas and their future perspectives are not clear.

3) We suggest to establish new microhabitats and Nature Reserves for WKHs in Latgale conserving not only forest habitats with high biological values and WKH bryophyte and lichen indicator species long-term conservation, but ensuring conservation also for other forest dwelling organisms and maintaining ecosystem services.

\section{ACKNOWLEDGMENTS}

Thanks is given to Forest State Service for data about (P)WKHs in Latgale. We are grateful to Sandra Ikauniece for fruitful discussions about forest habitats.

\section{REFERENCES}

[1] Heinken T., Weber E. Consequences of habitat fragmentation for plant species: Do we know enough? Perspectives in Plant Ecology, Evolution and Systematics, 15. 2013, pp. 205- 216.

[2] Aune K., Jonsson B. G., Moen J. Isolation and edge effects among woodland key habitats in Sweden: Is forest policy promoting fragmentation? Biological Conservation, 124. 2005, pp. 89-95.

[3] Berglund H., Jonsson B.G. Verifying an extinction debt among lichens and fungi in Northern Swedish Boreal forests. Conservation Biology, Vol. 19 No 2. 2005, pp. 338-348.

[4] Dumpe L. Mežu izmantošanas attīstība Latvijā. In: Latvijas mežu vēsture līdz 1940. gadam. Rīga: Pasaules Dabas fonds, 1999.

[5] SIA Grupa 93. Stratēgiskais ietekmes uz vidi novērtējums. Vides pārskata projekts. Rīga, 2010

[6] Ek T., Suško U., Auziņš R. Inventory of woodland key habitats. Methodology. Riga: 2002.

[7] Anonīms. Meža platību sadalījums. Latgales plānošanas reǵiona teritoriālais plānojums. Mežu platību sadalījums. 2007. http://www.latgale.lv/lv/ padome/planosana

[8] Anonīms. Noslēguma pārskats. Dabisko meža biotopu inventarizācija Latvijas valsts mežos. 2003.

[9] MK Ministru kabineta noteikumi Nr. 940. Noteikumi par mikroliegumu izveidošanas un apsaimniekošanas kārtību, to aizsardzību, kā arī mikroliegumu un to buferzonu noteikšanu. 2012.

[10] MK Ministru kabineta noteikumi Nr.421. Noteikumi par īpaši aizsargājamo biotopu veidu sarakstu. 2000.

[11] Jaunputniņš A. Austrumlatvija. In: Latvijas PSR geogrāfija. Rīga: Zinātne, 1975.

[12] Latvijas dabas fonds. Rāznas nacionālā parka dabas aizsardzības plāns. Jaunmārupe: Latvijas dabas fonds, 2009.

[13] Daugavpils novada dome, Daugavpils Universitāte, Sistemātiskās biologijas institūts (DND, DU, SBI) . Dabas parks "Daugavas loki" dabas aizsardzības plāns. Daugavpils: 2010.

[14] Mežaka A., Brūmelis G., Piterāns A. Epiphytic bryophyte and lichen communities in relation to tree and forest stand variables in Populus tremula forests of south-east Latvia. Acta Biologica Universitatis Daugavpiliensis, Suppl. 2. 2010, pp. 18

[15] Ikauniece S., Brūmelis G., Zariņš J. Linking woodland key habitat inventory and forest inventory data to prioritize districts needing conservation efforts. Ecological Indicators, 14. 2012, pp. 18-26.

[16] Putna S., Mežaka A. Preferences of epiphytic bryophytes for forest stand and substrate in North-East Latvia. Folia Cryptogamica Estonica, 5. 2014, pp. 75-83.

[17] Jüriado I., Paal J., Liira J. Epiphytic and epixylic lichen species diversity in Estonian natural forests. Biodiversity and Conservation, 8. 2003, pp. 1587-1607.

[18] Rogers P.C., Ryel R.J. Lichen community change in response to succession in aspen forests of the Southern Rocky Mountains. Forest Ecology and Management, 256. 2008, pp. 1760-1770.

[19] Hanski I., Ovaskainen O. Extinction debt at extinction threshold. Conservation Biology, Vol. 16 No 3. 2001, pp. 666673.

[20] Ellis C.J., Coppins B.J. 19th century woodland structure controls stand-scale epiphyte diversity in present-day Scotland. Diversity and Distribution, 13. 2007, pp. 84-91.

[21] Paltto H., Nordén B., Götmark F., Franc N. At which spatial and temporal scales does landscape context affect local density of Red Data Book and Indicator species? - Biological Conservation, 133. 2006, pp. 442-454.

[22] Margules C.R., Pressey R.L. Systematic conservation planning. Nature, 405. 2000, pp. 243-253.

[23] Opdam P. Coninx I., Dewulf A., Steingrövere E., Vos C., van der Wal M. Framing ecosystem services: Affecting behaviour of actors in collaborative landscape planning? Land use policy, 46. 2015, pp. 223-23.

[24] Castro A.J. , Martín-Lopez B. , Lopez E. , Plieninger T., Alcaraz-Segura D. , Vaughn C.C.,Cabello J. "Do protected areas networks ensure the supply of ecosystem services? Spatial patterns of two nature reserve systems in semi-arid Spain" Applied Geography, 60. 2015, pp. 1-9. 